\title{
感染性人工股関節の治療経験
}

\author{
熊本整形外科病院 \\ 河野 正 典・坂口満 \\ 矢渡 健一・岩 永貴 行
}

\section{Treatment for Infected Total Hip Arthroplasty}

\author{
Masanori Kawano, Mitsuru Sakaguchi, Kenichi Yawatari, \\ and Takayuki Iwanaga \\ Kumamoto Orthopedic Hospital, Kumamoto, Japan
}

\begin{abstract}
We treated four patients with infected total hip arthroplasties for 16 years. We reviewed onset time of infection, organism, and the timing of reimplantation. Cultures grew staphylococcus epidermidis in two hips, MRSA in one hip, and enterococcus faecium in one hip. Three joints acutely infected were cured by continuous drainage and could retain prosthesis, and 2 - stage reimplantation on one joint that was infected late. Debridement with retention of the prosthesis is a potentially successful treatment for early postoperative infections and should not be attempted in patients with chronic infection.
\end{abstract}

Key words : total hip arthroplasty (人工股関節置換術), infection (感染症), drainage (ドレナージ), reimplantation (再置換術)

\section{は じめに}

人工股関節置換術 (THA) 後の合併症の中で感染 症は重大な合併症の一つである ${ }^{1,3,4,6)}$. 今回, 我々が 施行した THA 症例のうち術後深部感染症を発症した 症例を調査しその治療法を検討した。

\section{症例}

対象は昭和 63 年から平成 15 年 7 月までに当院で施 行したTHA771症例のうち著者らが施行した THA365 症例とした。術後深部感染症を発症した症 例は男性 1 例女性 3 例の 4 症例 4 関節である. 感染発 症時年齢は 55 歳から 84 歳で平均 69 歳であった。基 礎疾患は变形性股関節症が 3 症例，股関節強直 1 症例 であった。抗菌剤の投与は術前に塩酸セフォチアム （ハロスポア，以下 CTM） $1 \mathrm{~g}$ 投与し，術後は CTM $2 \mathrm{~g}$ を 5 日間投与していた。これらの群に扔いて感染
発症時期, 起炎菌, 治療方法などを検討した.

\section{結果}

全体の感染発症率は $1.1 \%$ であった。初回手術後の 感染症は 2 症例で再置換術後の感染症例は 2 症例であっ た. 手術後 3 ヶ月以内を早期感染症, 3 ヶ月以上を遅 発性感染症とすると, 遅発性感染症は 1 症例で 3 症例 が早期感染症であった。起炎菌は MRSA が 1 症例で, 遅発性感染症例では弱毒菌の Enterococcus faecium 屯認められた。早期感染症例の 3 症例は感染徵候が現 れてすべて 3 日以内に洗浄, 病巣掻爬, ドレナージを 行い，全症例インプラントを抜去せず温存できた，遅 発性発症の 1 症例はインプラントの抜去を行った後, セメントビーズを挿入し 12 週間待機し, 再置換術を 行い沈静化が得られた. 現在のところ全例 1 本杖歩行 を行っている. 


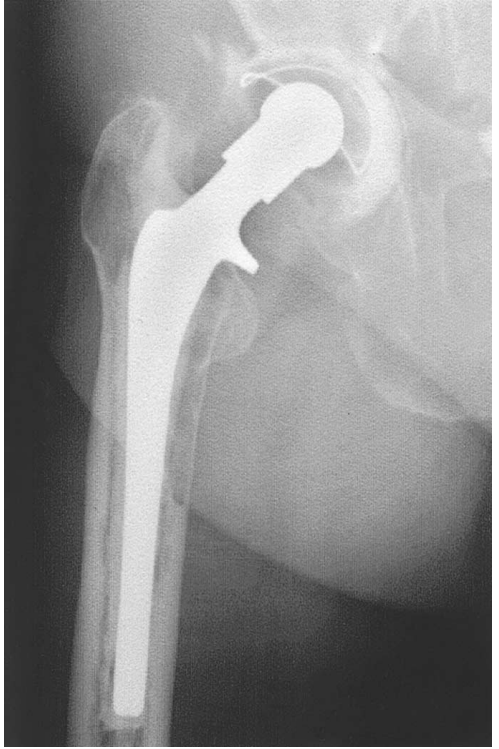

図 1 ステム周囲の loosening と bone stockの減少がみられる。

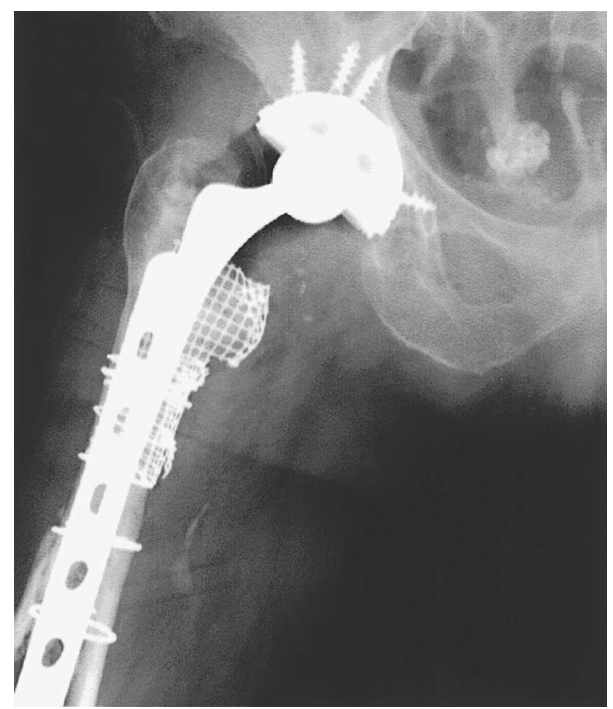

図 2 Revision 後

\section{症 例 提 示}

症例 $1: 72$ 歳, 女性. 平成 8 年, 右变形性股関節症 に対しチェンレー型人工股関節にて THA を施行した.

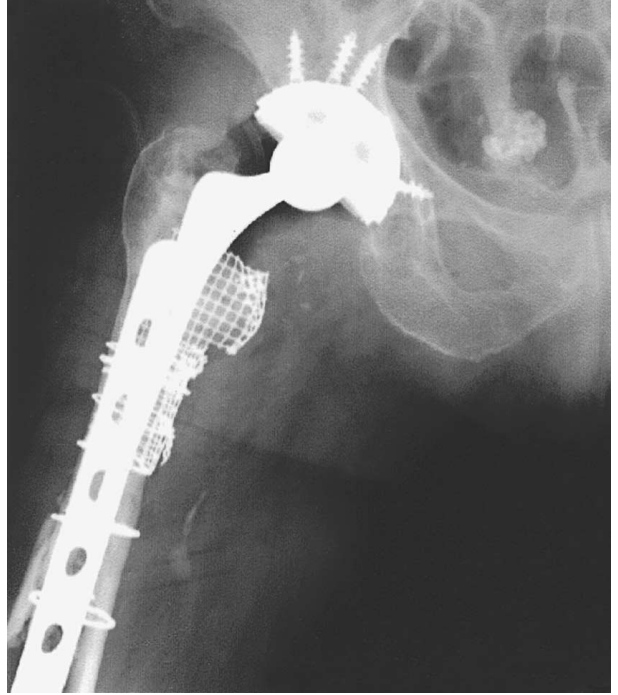

図 3 loosening はないが関節腔内に液 体貯留がみられる。

平成 15 年 3 月, $\mathrm{X}$ 線上, ステム周囲に loosening を 認めた。発熱なく炎症反応も陰性であった，5月，エ クセター型人工股関節を用いて右 THA 再置換術を 施行した。この際，ステムの骨䯣腔掻爬中に大腿骨骨 折を起こしたため，インパクションボーングラフトを 行いドールマイルズプレートとメッシュを使用し固定 した. しかし術後約 1 力月で，リハビリ中に脱臼，整 復後 2 週間で再び脱臼を起こした。このため臼蓋 componentのみ再置換術を行った。術後 6 日目，突 然の高熱と局所の疼痛, 発赤を認めた。当日, 掻爬, 洗浄を行い, ペンローズによるドレナージを開始した. 培養により MRSA が検出された。 ドレナージ開始後 17 日目，炎症反応の上昇および $\mathrm{X}$ 線上，液体の関節 腔内貯留像を認めたため, 生食とイソジンによる持続 洗浄を開始した。持続洗浄は 9 日間行い，4 日間かけ てチューブに陰圧をかけながら抜去した。初回術前お よび術後の X 線である（図 1，2）。術前はステム周 囲に bone stock の減少と loossening がみられる. 感染期の X 線である (図 3). loosening はみられて いないが関節腔内に液体貯留がみられる。この症例で の治療内容および炎症反応などの経過を示す。術後は CTM からトシル酸スルタミシリン（ユナシン，以下 SBTPC）へ変更したが，培養にて MRSA と判明し 


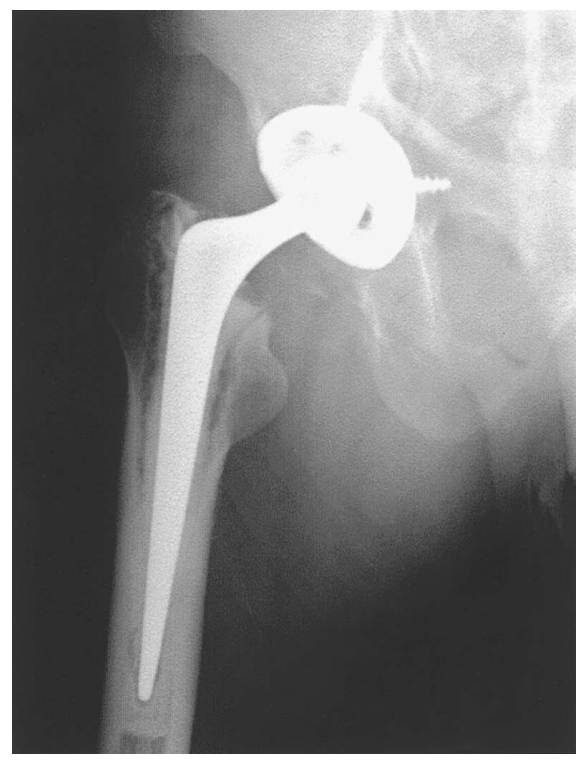

図４ステム周囲に loosening がみられる.

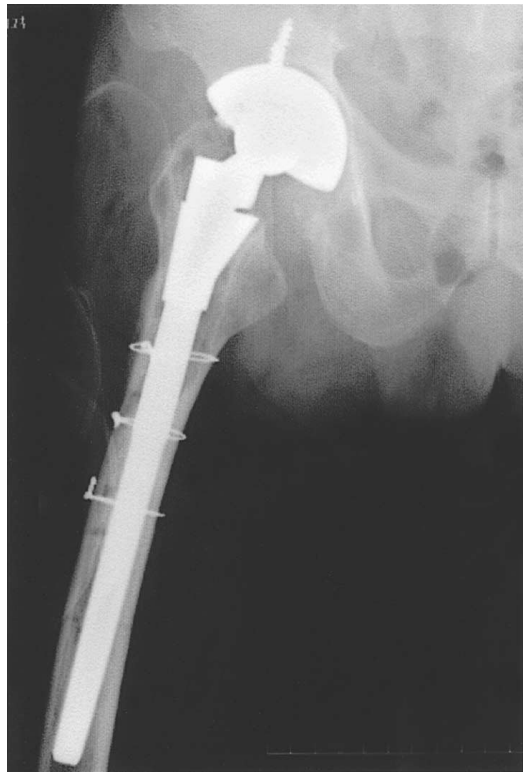

図 52 期的再置換術を行い，経過良 好である。

た時点でホスホマイシン（ホスホマイシン S，以下 FOM)，スルバクタム・セフォペラゾンナトリウム
表 1 我々の THA 後感染症例に対する治療方法

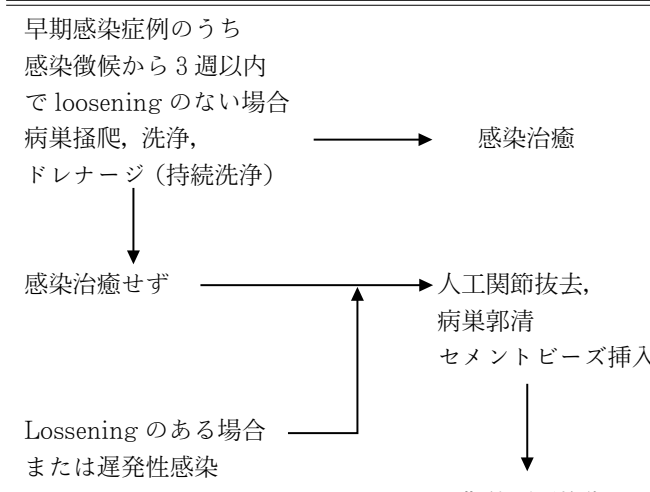

二期的再置換術

(スルペラゾン，以下 $\mathrm{SBT} / \mathrm{CPZ})$, テイコプラニン （タゴシット，以下 TEIC）による 3 者併用療法に切 り替えた．持続洗浄は炎症反応の陰性化と培養での 3 回以上連続して陰性であることにより抜去した。

症例 $2: 85$ 歳男性. 平成 13 年 3 月に右变形性股関 節症に対し, エクセター型人工股関節にて右 THA を 施行した. 約 9 か月後経過して右股関節痛が出現した. 平成 14 年 3 月 $\mathrm{X}$ 線上, clear zone 認め, 骨シンチ にて同部位に up take がみられた。 その 2 日後にイ ンプラントを抜去し，掻爬，抢よびセメントビーズを 挿入した。培養にて Enterococcus faecium が検出さ れた. 術後 3 週間抗生剂点滴し, 術後 12 週の時点で セメントビーズを抜去し $\mathrm{S}-\mathrm{ROM}$ 型人股関節にて再 置換術を施行した。感染期に明らかな clear zone が みられる（図 4). 2 期的再置換術を行い，現在経過良 好である（図 5)。術後は CTM であったが SBTPC へ変更し, 術後 3 週の時点で 3 者併用に切り替えた. セメントビーズ抜去後に一時的に炎症反応の上昇をみ たがとくに問題なかった.

考察

Krasin $~^{5)}$ は 2 期的再置換術が治療の主流である 中, 適応症例を㛜密に選択することで洗浄, debridement, 抗生剂投与により感染の沈静化が得ら れ，インプラントの温存が可能となると述べている.

Garvin $^{2)}$ らは THA の感染症例に対しインプラン 卜を温存できる症例は，1）感染徵候がみられて $3 \sim 4$ 週以内，2）培養にて感受性のある抗生剂が存在する, 
表 2 MRSA 感染症に対して行った投与方法

\begin{tabular}{l} 
三者併用療法 \\
1), FOM $2 \mathrm{~g}+$ 蒸留水 $20 \mathrm{ml} \quad 3 \sim 5$ 分かけて静注 \\
60 分後に \\
2), SBT/CPZ2g $+5 \%$ ブドゥ糖液 $250 \mathrm{ml}$ \\
60 分かけて点滴 \\
3), TEIC400mg +生食 $100 \mathrm{ml}$ \\
60 分かけて点滴 \\
第 1 日目 $\quad: 1) \rightarrow 2) \rightarrow 3)$ を 1 日 2 回 \\
2 日目以降 $\quad:$ 朝のみ 1$) \rightarrow 2) \rightarrow 3)$, 夕は 1$) \rightarrow 2)$ \\
\hline
\end{tabular}

3） loosening がみられない，4）前回手術による過剰 な㓔痕組織がない, 以上の条件を満たすものであると 述べている.

われわれの考える THA 後感染症例に対する治療方 針を示す (表 1). 手術後 3 ヶ月以内の早期感染症例 のうち感染徵候が現れてから 3 週以内で, かつ loosening のない症例に対しては人工関節を抜去するの ではなく，まず抗菌剤の投与を行い，徹底的な病巣掻 爬とドレナージおよび持続洗浄にて感染の沈静化を試 みる. 症例 1 で提示したように, MRSA による感染 症でもインプラントの温存および感染の沈静化が得ら れた。我々がMRSA 感染症に対して行った抗菌剂の 投与方法を示す（表 2).まずFOM により biofilm を脆弱化させ 60 分後に SBT/CPZ を投与することで MRSA の $\beta$ ラクタマーゼを阻害し， 60 分後に投与す る TEIC の菌体への到達が容易になるとされている.

手術後 3 ヶ月以内の早期感染症例であっても感染徵 候が現れてから 3 週間以上経過している症例や loosening の認められる症例, また遅発性感染症例の 全例については人工関節を抜去し，2 期的再置換術を 行っている. 今回, 文献㧍よび我々の考える治療方針 に基づいた方法で感染の沈静化を得ることができた.

\section{ま と め}

1) 今回の我々の調査では THA 術後の感染率は 1.1 \%であった。

2 ) MRSA 症例を含めた早期の THA 感染症例に対 し抗菌剂投与ならびに病巣掻爬，持続洗浄にて感染 の沈静化が得られる可能性があると考えられた.

3 ）遅発性症例に対してはインプラントを抜去し 2 期 的再置換術を施行したことで感染の沈静化を得た。

\section{参 考 文 献}

1) Donnelly, R, E., : Advances in treating the infected total hip replacement. JAAPA., 16 : 49-52, 2003.

2) Garvin, K. L., Hanssen, A , D. : Infection after total hip arthroplasty. J. Bone Joint Surg. Am., 77(10) : 1576-88, 1995.

3) Gusenoff, J, A., et al. : Outcome and management of infected wounds after total hip arthroplasty. Ann. Plast. Surg., 49(6) : 587-92, 2002.

4) Haddad, F. S., et al : The treatment of the infected hip replacement. Clin. Orthop., 369 : 144-56, 1999.

5) Krasin, et al. : Could irrigation, debridement and antibiotic therapy cure an infection of a total hip arthroplasty?. J. Hosp. Infection., 47 : 235-238, 2001.

6) Salvati, E. A. et al. : The infected total hip arthroplasty. Instr. Course Lect., 52 : 223-45, 2003. 